\title{
USVL-370, a Zucchini yellow mosaic virus-resistant Watermelon Breeding Line
}

\section{Amnon Levi ${ }^{1}$}

U.S. Department of Agriculture, Agricultural Research Service, U.S. Vegetable Laboratory, 2700 Savannah Highway, Charleston, SC 29414

\section{Karen R. Harris-Shultz}

U.S. Department of Agriculture, Agricultural Research Service, 115 Coastal Way, Tifton, GA 31793

\section{Kai-shu Ling}

U.S. Department of Agriculture, Agricultural Research Service, U.S. Vegetable Laboratory, 2700 Savannah Highway, Charleston, SC 29414

Additional index words. Citrullus, potyvirus, disease resistance, DNA marker, eukaryotic elongation factor, genotyping, ELISA

USVL-370 is a novel watermelon line [Citrullus lanatus (Thunb.) Matsum. \& Nakai] with resistance to the Zucchini yellow mosaic virus-Florida strain (ZYMV-FL) (Provvidenti, 1991; Provvidenti et al., 1984). The new breeding line is homozygous for the recessive eukaryotic elongation factor $e I F 4 E$ allele associated with ZYMV resistance identified from Plant Introduction (PI) 595203 by Ling et al. (2009) and Harris et al. (2009). This breeding line was developed at the U.S. Vegetable Laboratory, U.S. Department of Agriculture, Agricultural Research Service, Charleston, SC.

\section{Origin}

Development of USVL-370 began in 2009 with our finding that the eIF4E allele of PI 595203 is associated with resistance to ZYMV-FL (Harris et al., 2009; Ling et al., 2009). USVL-370 was developed through a breeding process that first included the generation of an $\mathrm{F}_{2}$ population derived from a cross between the ZYMV-FL-resistant PI 595203 (Guner, 2004; Guner and Wehner, 2004) and the highly susceptible heirloom watermelon cultivar New Hampshire Midget (Fig. 1). The breeding process employed stringent phenotypic ratings of plants inoculated with ZYMV-FL in the greenhouse, an enzyme-linked immunosorbent assay (ELISA) test, and marker-assisted selection using two cleaved amplified polymorphic sequence (CAPS) markers in the eIF $4 E$ gene locus (CAPS1, CAPS2) as described by Ling et al. (2009) (Fig. 2) and a sequenced charac-

Received for publication 18 Sept. 2015. Accepted for publication 13 Oct. 2015.

We thank Laura Massey and John Coffey for their technical assistance and dedicated work in the development of this breeding line.

${ }^{1}$ Corresponding author. E-mail: amnon.levi@ars. usda.gov. terized amplified region marker (designated as ZYRP) associated with ZYMV-FL resistance (Harris et al., 2009).

Young $\mathrm{F}_{2}$ plants (2-3 leaf stage) were inoculated twice with ZYMV-FL (1 week between inoculations). Three weeks following the first inoculation, the plants were evaluated and plants that did not have any
ZYMV symptoms and had no virus present in the ELISA test were selected. DNA samples were isolated from these resistant $F_{2}$ plants and were evaluated for the three molecular markers mentioned above. In contrast with ZYMV-susceptible control plants that were heterozygous or homozygous for the susceptible $e I F 4 E$ allele, the ZYMV-resistant plants were all homozygous for the $e I F 4 E$ allele derived from PI 595203 (as shown in Fig. 2). Each of the resistant $F_{2}$ plants was selfpollinated to produce an $\mathrm{F}_{3}$ family. Resistance to ZYMV was confirmed in homozygous-resistant $\mathrm{F}_{3}$ families and an $\mathrm{F}_{3}$ plant that showed no virus symptoms, no virus presence in an ELISA test, and that was confirmed to be homozygous for the eIF4E allele derived from PI 595203 (Fig. 2) was selected and crossed to 'Charleston Gray'. Ten $F_{1}$ plants derived from this cross were genotyped and a plant that was confirmed to have the $e I F 4 E$ allele of PI 595203 was selfpollinated to produce $F_{2}$ seeds. Thirty young $\mathrm{F}_{2}$ plants were tested for ZYMV resistance and a plant that showed no ZYMV symptoms, no virus presence in an ELISA test, and was homozygous for the PI 595203 eIF4E allele was selected and backcrossed with 'Charleston Gray' to have $\mathrm{BC}_{1}$ plants. A $\mathrm{BC}_{1}$ plant that contained the PI 595203 eIF4E allele was self-pollinated to produce $\mathrm{BC}_{1} \mathrm{~F}_{2}$ seeds. As described in the previous stage, $30 \mathrm{BC}_{1} \mathrm{~F}_{2}$ plants were evaluated and

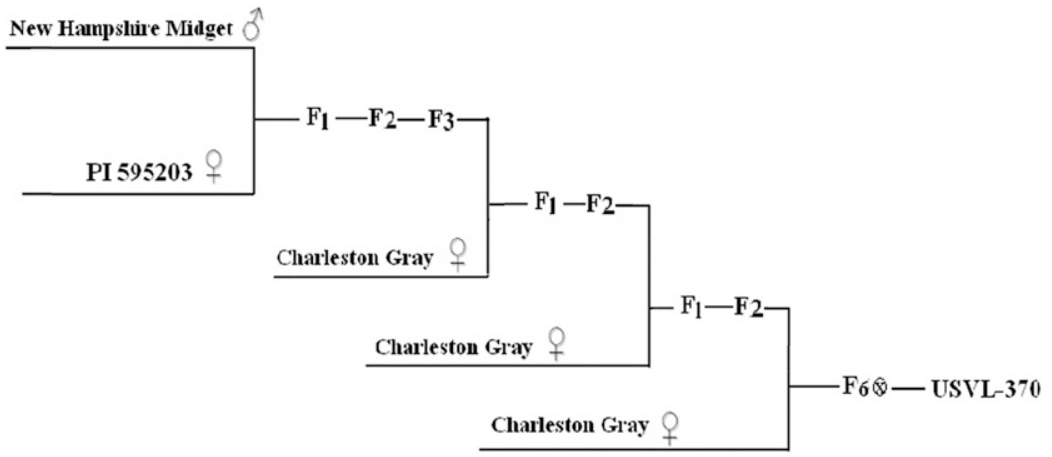

Fig. 1. Pedigree of USVL-370 showing the route of incorporating the Zucchini yellow mosaic virusresistant gene locus into the genome of the watermelon cultivar Charleston Gray (Citrullus lanatus var. lanatus).

\section{$\begin{array}{llllllllllllllllllll}M & 1 & 2 & 3 & 4 & 5 & 6 & 7 & 8 & 9 & 10 & 11 & 12 & 13 & 14 & 15 & 16 & 17 & 18 & M\end{array}$}

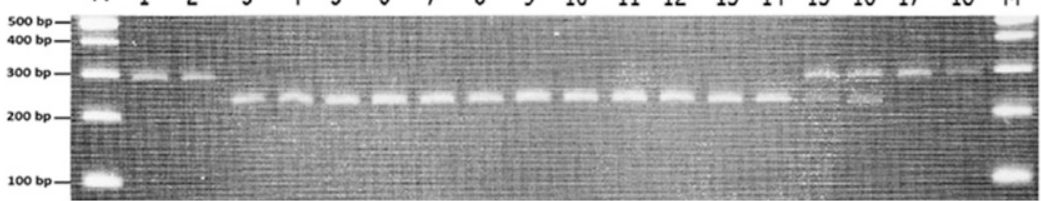

Fig. 2. Genotyping of plants throughout the breeding process of USVL-370 using the cleaved amplified polymorphic sequence-2 (CAPS-2) marker for the eIF4E allele. Genotyping of CAPS-2 was performed using the primer pair KL08-03, 5'-AAAGCTACACCCACGGAAGA and KL08-04, 5'-CTCCAGAACTCCTCGACAGTAG and digestion of their polymerase chain reaction amplicon with restriction enzyme Pas I (as described by Harris et al., 2009; Ling et al., 2009). Lanes 1 and 2 are the susceptible watermelon cultivars New Hampshire Midget and Charleston Gray, respectively (268bp fragment). Lane 3 is the Zucchini yellow mosaic virus (ZYMV)-resistant PI 595203 (211-bp fragment). Lanes 4-14 (211-bp fragment) are ZYMV-resistant $\mathrm{BC}_{3} \mathrm{~F}_{2}$ plants, homozygous for the eIF4E allele derived from PI 595203. Lanes 15-18 are ZYMV-susceptible $\mathrm{BC}_{3} \mathrm{~F}_{2}$ plants segregating for the eIF $4 E$ allele (lanes 15 and 16 are heterozygous, whereas lanes 17 and 18 are homozygous for the eIF $4 E$ allele from the parent cultivar). 
Table 1. Zucchini yellow mosaic virus (ZYMV) disease severity ${ }^{\mathrm{z}}$ for the susceptible watermelon cultivars Charleston Gray and Desert King, and the resistant lines PI 595203 and USVL-370.

\begin{tabular}{lcr}
\hline Accession & Mean $^{\mathrm{y}}$ & SEM $^{\times}$ \\
\hline Charleston Gray & $3.6 \mathrm{a}$ & 0.45 \\
Desert King & $3.6 \mathrm{a}$ & 0.10 \\
PI 595203 & $1.0 \mathrm{~b}$ & 0.00 \\
USVL-370 & $1.3 \mathrm{~b}$ & 0.03 \\
\hline
\end{tabular}

${ }^{\mathrm{z}}$ Disease severity was evaluated 3 weeks after the first inoculation, and plants were randomized in five blocks (randomized complete block design) in the greenhouse (day and night temperatures of $26^{\circ} \mathrm{C}$ and $18{ }^{\circ} \mathrm{C}$, respectively) and evaluated for virus symptoms 3 weeks after inoculation. The rating system used healthy uninfected plants of watermelon cultivars as reference control to identify sick plants resulting from virus infection. Virus disease severity was rated as: 1 - no symptoms; 2 - slight mosaic on leaves; 3 mosaic patches and/or necrotic spots on leaves or leaves near apical meristem are deformed, have yellow color, and reduced leaf size; 4 - extensive mosaic appearance and leaf deformation and plant is stunted; and 5-extensive mosaic appearance and sever leaf deformation and plant is entirely stunted or dead.

${ }^{y}$ Mean separation within columns by Fisher's protected least significant test, $P \leq 0.05$.

${ }^{\mathrm{x}} \mathrm{SE}$ of the mean.

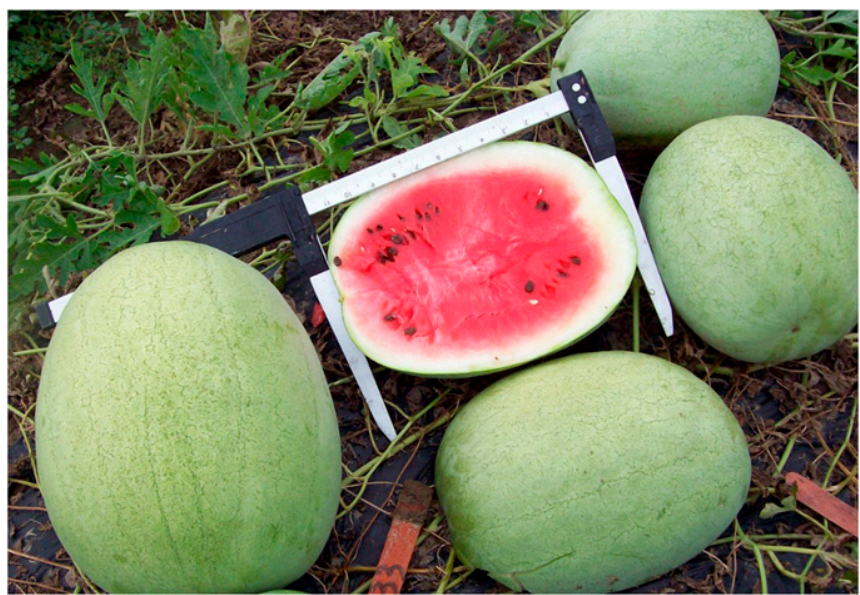

Fig. 3. USVL-370 fruits harvested in the field at Charleston, SC, during Summer 2012.

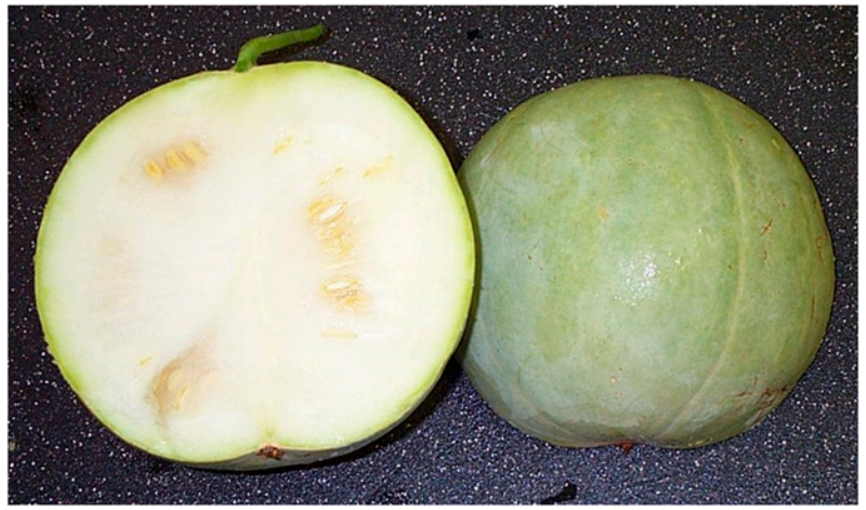

Fig. 4. Fruit of the Zucchini yellow mosaic virus-resistant PI 595203 harvested in the field at Charleston, SC, in Summer 2013. a plant that showed no ZYMV symptoms, no virus presence in the ELISA test, and was homozygous for the PI 595203 eIF4E allele was selected and further backcrossed with 'Charleston Gray' to produce $\mathrm{BC}_{2}$ seeds. The selection process was further advanced through self-pollination to produce $\mathrm{BC}_{2} \mathrm{~F}_{2}$ seeds and a resistant $\mathrm{BC}_{2} \mathrm{~F}_{2}$ plant was selected and advanced through selection criteria above in five generations to produce $\mathrm{BC}_{2} \mathrm{~F}_{7}$ resistant plants, designated as USVL-370 (Fig. 1).

In greenhouse tests at the U.S. Vegetable Laboratory during 2013 and 2014, the USVL-370 plants showed significantly higher resistance to ZYMV compared with the heirloom watermelon cultivars Charleston Gray or Desert King that were used as positive controls (Table 1).

\section{Description}

In contrast with the elongated watermelon fruit of the recurrent backcross parent 'Charleston Gray', the USVL-370 has ovular fruit (rind thickness is $\approx 1.0^{\prime \prime}$ ) (Table 2). In field trials in Charleston, SC (2012-14), USVL-370 plants produced an average of 1.4 large mature fruits per plant (Table 2; Fig. 3) in mid-late season (78$82 \mathrm{~d}$ postplanting), which is comparable with 'Charleston Gray' or 'Crimson Sweet'. The mature fruits of USVL-370 have a light green-gray dappled rind, resembling that of 'Charleston Gray', and light red flesh color with a sweet flavor, but with a lower solid soluble content compared with traditional heirloom cultivars (Table 2). The USVL-370 watermelon flesh is firm with a slight crispy texture and does not exhibit hollow heart. The fruit contains light brown seeds $(7.0 \mathrm{~mm}$ long and $4 \mathrm{~mm}$ wide) (Fig. 3). Overall, the USVL-370 fruits are distinct from its donor parent PI 595203 (globular fruit with light green-gray rind and white flesh with dense texture and slightly bitter taste and white seeds; Fig. 4) or the recurrent parent 'Charleston Gray'. The ovular fruit of USVL-370 was most likely inherited from PI 595203 and/or 'New Hampshire Midget' that have globular and ovular watermelon fruit shape, respectively (Fig. 4). The eukaryotic elongation factor $e I F 4 E$ allele

Table 2. Watermelon fruit characteristics (mean \pm SEM) for USVL-370 and three American heirloom cultivars grown in a field of the U.S. Vegetable Laboratory, Charleston, SC, in Summer 2014.

\begin{tabular}{|c|c|c|c|c|c|c|c|c|c|}
\hline Accession & Shape & Length $(\mathrm{cm})$ & Width (cm) & Wt (kg) & $\begin{array}{l}\text { Number of } \\
\text { fruits }\end{array}$ & Rind thickness & Rind pattern & Flesh & Brix \\
\hline Charleston Gray & Elongated & $48.0(2.3)$ & $21.1(0.4)$ & $11.0(2.7) \mathrm{a}$ & $1.2 \mathrm{a}$ & $0.48(0.02) \mathrm{b}$ & Light green gray & Light red & $10.9(0.3) \mathrm{b}$ \\
\hline Crimson Sweet & Ovular & $29.3(1.5)$ & $24.7(1.1)$ & $8.9(1.0) \mathrm{a}$ & $1.8 \mathrm{a}$ & $0.52(0.03) b$ & $\begin{array}{l}\text { Light green with } \\
\text { dark stripes }\end{array}$ & Red & $10.5(0.5) b$ \\
\hline Dixie-Lee & Ovular & $27.8(2.0)$ & $24.2(1.8)$ & $11.6(1.4) \mathrm{a}$ & $2.3 \mathrm{a}$ & $0.75(0.06) \mathrm{ab}$ & $\begin{array}{l}\text { Dark green stripes } \\
\text { on a light green } \\
\text { background }\end{array}$ & Red & $9.9(0.5) \mathrm{ab}$ \\
\hline
\end{tabular}

${ }^{\mathrm{z}}$ Data were collected from four plots (three plants in each plot, at a distance of 3 feet between them) arranged in a randomized complete block design with 9 feet between plots. Data are presented as mean \pm SEM.

${ }^{\mathrm{y}}$ Mean separation within columns by Fisher's protected least significant test, $P \leq 0.05$. 
is positioned on chromosome 3 of watermelon genome (Guo et al., 2013). Quantitative trait loci (QTL) associated with watermelon fruit shape were genetically mapped to chromosome 3 (Ren et al., 2014), whereas additional putative QTL associated with fruit shape were mapped on chromosomes 4,7 , and 10 of the watermelon genome using genome-wide association mapping approach (Reddy et al., 2015). It might be that the major QTLs associated with fruit shape on chromosome 3 were selected together with the eIF4E allele of PI 595203 to produce ovular fruits (Fig. 3).

Heirloom watermelon cultivars share a narrow genetic base (Levi et al., 2001), and there is a continuous need to enhance resistance to diseases and potyviruses among these cultivars. USVL-370 should be useful in breeding programs aiming to incorporate ZYMV resistance into commercial cultivars while reducing linkage drag with undesirable fruit traits.

\section{Seed Availability}

Small samples of seed of USVL-370 are available for distribution to interested research personnel and plant breeders who make written request to Dr. Amnon Levi or Dr. Kai-shu Ling, U.S. Vegetable Laboratory, U.S. Department of Agriculture, Agricultural Research Service, 2700 Savannah Highway, Charleston, SC 29414-5334. Seed of USVL-370 will also be submitted to the
National Plant Germplasm System where it will be available for research purposes, including the development and commercialization of new cultivars. It is requested that appropriate recognition of the source be given when this germplasm contributes to research or development of a new breeding line or cultivar.

\section{Literature Cited}

Guo, S., J. Zhang, H. Sun, J. Salse, W.J. Lucas, H. Zhang, Y. Zheng, L. Mao, Y. Ren, Z. Wang, J. Min, X. Guo, F. Murat, B.K. Ham, Z. Zhang, S. Gao, M. Huang, Y. Xu, S. Zhong, A. Bombarely, L.A. Mueller, H. Zhao, H. He, H. Zhang, Z. Zhang, S. Huang, T. Tan, E. Pang, K. Lin, Q. Hu, H. Kuang, P. Ni, B. Wang, J. Liu, Q. Kou, W. Hou, X. Zou, J. Jiang, G. Gong, K. Klee, H. Schoof, Y. Huang, X. Hu, S. Dong, D. Liang, J. Wang, K. Wu, Y. Xia, X. Zhao, Z. Zheng, M. Xing, X. Liang, B. Huang, T. Lv, J. Wang, Y. Yin, H. Yi, R. Li, M. Wu, A. Levi, X. Zhang, J.J. Giovannoni, J. Wang, Y. Li, Z. Fei, and Y. Xu. 2013. The draft genome of watermelon (Citrullus lanatus) and resequencing of 20 diverse accessions. Nat. Genet. 45:51-58.

Guner, N. 2004. Papaya ringspot virus watermelon strain and Zucchini yellow mosaic virus resistance in watermelon. Department of Horticultural Sciences, North Carolina State Univ., Raleigh, PhD Diss.

Guner, N. and T.C. Wehner. 2004. Resistance to a severe strain of zucchini yellow mosaic virus in watermelon, p. 223-230. In: A. Lebeda and H.S. Paris (eds.) Progress in cucurbit genetics and breeding research. Proc. 8th EUCARPIA Mtg. Cucurbitaceae 2004, Olomouc, Czech Republic.
Harris, K.R., K.S. Ling, W.P. Wechter, and A. Levi. 2009. Identification and utility of markers linked to the zucchini yellow mosaic virus resistance gene in watermelon. J. Amer. Soc. Hort. Sci. 134:529-534.

Levi, A., C.E. Thomas, T.C. Wehner, and X. Zhang. 2001. Low genetic diversity indicates the need to broaden the genetic base of cultivated watermelon. HortScience 36:10961101.

Ling, K.S., K.R. Harris, J.D.F. Meyer, A. Levi, N. Guner, T.C. Wehner, A. Bendahmane, and M.J. Havey. 2009. Non-synonymous single nucleotide polymorphisms in the watermelon $e I F 4 E$ gene are closely associated with resistance to zucchini yellow mosaic virus. Theor. Appl. Genet. 120:191-200.

Provvidenti, R. 1991. Inheritance of resistance to the Florida strain of Zucchini yellow mosaic virus in watermelon. HortScience 26:407408.

Provvidenti, R., D. Gonsalves, and H.S. Humaydan. 1984. Occurrence of zucchini yellow mosaic virus in cucurbits from Connecticut, New York, Florida, and California. Plant Dis. 68:443-446.

Reddy, U.K., L. Abburi, V.L. Abburi, T. Saminathan, R. Cantrell, V. Gopinath Vajja, R. Reddy, Y.R. Tomason, A. Levi, T.C. Wehner, and P. Nimmakayala. 2015. A genome-wide scan of selective sweeps and association mapping of fruit traits using microsatellite markers in watermelon. J. Hered. 106:166-176.

Ren, Y., C. McGregor, Y. Zhang, G. Gong, H. Zhang, S. Guo, H. Sun, W. Cai, J. Zhang, and Y. Xu. 2014. An integrated genetic map based on four mapping populations and quantitative trait loci associated with economically important traits in watermelon (Citrullus lanatus). BMC Plant Biol. 14:33. 